\title{
0 mais profundo é a pele
}

\author{
The most profound is the skin
}

Piel el más profundo

Emerson Elias Merhy ${ }^{1}$

Combater a colonialista antropologia do século XIX, eurocêntrica, e seus efeitos discriminação, exclusão, dominação, entre muitos outros - é fundamental para se abrirem novas pautas à antropologia e às ciências sociais em geral. Torna-se mais significativo quando vivemos em um "mundo" completamente distinto daquele: novas dinâmicas sociais e novas conformações dos grupos sociais vêm marcando como superados vários dos paradigmas então construídos.

Vemos que, para as lutas sociais, hoje, conta mais a conformação de grupos que apostam na autenticidade de modos de existência no entre dos processos capitalísticos de subjetivação, como o caso exemplar do movimento homossexual, buscando outra formulação à construção do comum na diversidade. O movimento pela criação de novos direitos, antes não imaginados, possibilita a noção de que o comum na diversidade é a consideração do diverso como enriquecimento das convivências, e não como ameaça, o que vem pautando, em várias frentes de luta, outras formas de se conceber o significado das lutas coletivas, que as visões sobre luta de classes não dão conta.

Movimentos de muitos matizes afirmam-se como biopotências numa época de sociedade de controle (Pelbart, 2003), o que já podia ser visto, desde algum tempo, em modos de luta como o de Antonin Artaud, que se dizia um estrangeiro na sua língua e apontava, com suas formas de viver, as possibilidades dos interstícios, do agir no entre os lugares instituídos, seja do olhar do dominante ou do dominado, abrindo pontos de vista do mesmo lugar. Talvez modos de existência desviantes sejam algo mais interessante do que formas antihegemônicas de viver.

No contemporâneo, esses desvios micropolíticos têm tido força de abrir linhas de fuga, como já vimos em certos movimentos de gênero ou de afirmação sexual. Guattari (1987) nos mostra intensamente esse tipo de aposta. Nessa direção, a noção de multidão - como o lugar da produção e emergência de coletivos - pode ser algo mais interessante, na medida em que sua conformação pode ser múltipla, conforme indicam Hardt e Negri $(2005,2001)$, não tendo que adquirir, obrigatoriamente, configurações já fechadas, a que uma interpretação marxista, mais clássica, nos obrigaria.

Por isso, experimento certa ambiguidade: à parte de me sentir convocado e atraído, verifico um paradigma que considero insuficiente para dar conta das

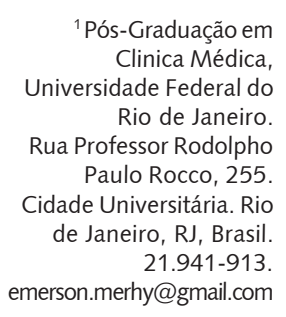


questões que temos vivido no âmbito das lutas sociais contemporâneas. Intrigou-me o uso feito da noção de hegemonia e o esforço de afirmar a grandeza da visão marxista. Sob uma leitura culturalista, busca a unicidade entre os campos constitutivos da condição humana - biológico e social -, subsumindo aquele por este. O texto repõe o clássico marxista ao afirmar que "não se faz a história das culturas e nem, portanto, sua interpretação, se não em relação à história concreta dos homens que as produzem e as utilizam dentro de contextos histórico-sociais determinados"; repõe a dialética marxista e a determinação em lugar dos coengendramentos e coproduções. Não que isso em si seja um erro ou um acerto, mas tais afirmações contêm efeitos e implicações. Não dá para apontar tudo isso sem consequências para o debate proposto.

O marxismo não tem nada de ingênuo, ao contrário, constrói, efetivamente, uma ontologia que expressa uma metafísica clara: faz-se, no trabalho, o homem como práxis social, assim, a formação social é devedora da natureza dos modos de produção. Uma sociedade capitalista, seja qual particularidade a habite, opera como sociedade capitalista, logo, seus grupos sociais são classes ou frações de classe, e suas relações se compõem a partir desse lugar determinante, o que nos faz olhar para qualquer fenômeno social, no campo da política ou da cultura, como resultado da condição social de classe. A noção de hegemonia, forjada no começo do século XX, trazia a compreensão de relações entre as classes sociais fundamentais da sociedade capitalista da época, olhada sob as perspectivas de Antonio Gramsci, trazendo, para o campo da luta social da classe operária italiana, o conjunto dos trabalhadores rurais, que eram atraídos pelos setores sociais dominantes, contribuindo de modo definitivo para a derrota das lutas emancipatórias dos operários organizados. O conceito de hegemonia tem precisão contextual e, como tal, é operatório. Um conceito mais ampliado ou transladado não o retira do campo doutrinário da sua produção.

Tenho controvérsias com esse conceito, mesmo quando aplicado no começo dos 1900 ou em qualquer outra época das lutas sociais, pois estou convencido de que implica a aposta na criação de uma vanguarda que domina uma massa - sob a perspectiva da adesão a um ideal de sociedade que não o seu, mas do outro, o da vanguarda. Como tal, querer ser hegemônico é querer trocar uma forma de dominação por outra e não produzir relações democráticas radicais, que suportem o (e dêem suporte ao) comum na diversidade. O comum na diversidade é diferente de "certo grau de heterogeneidade interna" onde "a cultura permanece globalmente coerente na medida em que os patrimônios culturais das diferentes camadas estão todos, funcionalmente, ao redor do funcionamento de uma mesma formação econômico-social".

A aplicação de uma antropologia de identificação gramsciana, em uma sociedade capitalista que se produz na lógica do trabalho imaterial, dentro de novas possibilidades de conformação dos grupos e coletivos sociais, onde há configurações diferentes da multidão que aí emerge (Negri, 2002) e das relações de poder que os constituem, não conseguiria compreender a própria mudança que vem ocorrendo no cerne das relações capitalistas de produção, neste século XXI, nas quais a forma de produção do valor se desloca do campo da mercadoria típica da produção industrial para o mundo da produção ordenado pelo conhecimento e pelas tecnologias relacionais, operando profundas modificações na antiga estética das classes sociais, tão caras ao pensamento marxista dos séculos anteriores.

Creio que vale um debate sobre isso no campo da antropologia que Seppilli expressa, conforme suas preocupações centrais. Entretanto, há outra grande questão no seu material que, também, leva-me a abrir outro tipo de debate: a busca de unidade entre os campos biológico e social, dos hominídios até os dias atuais da humanidade, para constituir uma visão mais universal e consensual sobre a condição humana. Intriga-me uma ideia de separação corpo e alma, colocada em dúvida desde o século XVII por Spinoza (2007), mas central no pensamento de Descartes (1973), que procurava, na Glândula Pineal, o lugar de passagem do corpo para a alma, e vice-versa. Senti algo equivalente na referência ao surgimento de "uma inteira nova disciplina", a psiconeuroendocrinoimunologia. O autor lembra que esta chega para "iniciar a construção de uma nova e mais avançada medicina científica", com capacidade de incorporação e integração das "grandes contribuições da biomedicina com as muitas contribuições sobre a função central da intermediação psíquica entre os estímulos relacionais e os processos corpóreos, produzidos aos poucos pela psicologia, pela antropologia e, em geral, pelas ciências sociais". 
Essa busca de unidade na ciência tem sido objeto de bons debates por parte da Filosofia da Ciência, e encontra, em um pensador como Boaventura de Sousa Santos (1989), reflexões que trazem questões interessantes para essa pretensão tão longa no pensamento ocidental, inclusive sobre a impossibilidade de sua realização; mas também há que se considerar outro aspecto: a própria noção de corpo. De que corpo estamos falando? De órgãos ou do prolongamento sem órgãos? (Merhy, 2009). Kant (1993) trouxe uma concepção mais sofisticada que o tema da Pineal (ou da psiconeuroendocrinoimunologia) quando nos apresentou um corpo de órgãos cujo mais nobre era a razão. Recoloco: o que é o corpo biológico?

Tudo isso está em (e abre) questão neste texto. Talvez tentar construir o forjamento de algo como o conceito de condição humana não seja muito viável, pela simples razão, como afirmava Foucault (1987), de que o homem não existe. Na mesma linha, Nietzsche (2001) havia dito que a pele é o mais profundo do homem, um ser que só ex-iste.

\section{Referências}

DESCARTES, R. Discurso do método. São Paulo: Abril Cultural, 1973.

FOUCAULT, M. As palavras e as coisas. São Paulo: Martins Fontes, 1987.

GUATTARI, F. Revolução molecular: pulsações políticas do desejo. São Paulo: Brasiliense, 1987.

HARDT, M.; NEGRI, A. Multidão: guerra e democracia na era do Império. Rio de Janeiro: Record, 2005

Império. Rio de Janeiro: Record, 2001.

KANT, I. Crítica da faculdade do juízo. Rio de Janeiro: Forense Universitária, 1993.

MERHY, E. A clínica do corpo sem órgãos, entre laços e perspicácias. Em foco a disciplinarização e a sociedade de controle. Lugar Comum Estud. Mídia, Cult. Democr., v.14, n.27, p.283-308, 2009.

NEGRI, T. O poder constituinte: ensaio sobre as alternativas da modernidade. Rio de Janeiro: DP\&A, 2002.

NIETZSCHE, F. Gaia ciência. São Paulo: Companhia das Letras, 2001.

PELBART, P. Vida capital: ensaios de biopolítica. São Paulo: Iluminuras, 2003.

SANTOS, B.S. Introdução a uma ciência pós-moderna. Rio de Janeiro: Graal, 1989.

SPINOZA, B. Ethica - Ética. Belo Horizonte: Autêntica, 2007. 